\title{
Genetic Diversity of Nine Non-Recombinant Potato virus Y Isolates From Three Biological Strain Groups: Historical and Geographical Insights
}

\author{
Kelsie J. Green, ${ }^{1,2}$ Arturo Quintero-Ferrer, ${ }^{1}$ Mohamad Chikh-Ali, ${ }^{1}$ Roger A. C. Jones, ${ }^{3,4, \dagger}$ and Alexander V. Karasev ${ }^{1,2, \dagger}$ \\ ${ }^{1}$ Department of EPPN, University of Idaho, Moscow, ID, U.S.A. \\ ${ }^{2}$ Bioinformatics and Computational Biology Program, University of Idaho, Moscow, ID, U.S.A. \\ ${ }^{3}$ Institute of Agriculture, University of Western Australia, Crawley, WA 6009, Australia \\ ${ }^{4}$ Department of Primary Industries and Regional Development, South Perth, WA 6151, Australia
}

\begin{abstract}
Potato virus Y (PVY) isolates from potato currently exist as a complex of six biologically defined strain groups all containing nonrecombinant isolates and at least 14 recombinant minor phylogroups. Recent studies on eight historical UK potato PVY isolates preserved since 1984 found only nonrecombinants. Here, four of five PVY isolates from cultivated potato or wild Solanum spp. collected recently in Australia, Mexico, and the U.S.A. were typed by inoculation to tobacco plants and/or serological testing using monoclonal antibodies. Next, these five modern isolates and four additional historical UK isolates belonging to biological strain groups $\mathrm{PVY}^{\mathrm{C}}, \mathrm{PVY}^{\mathrm{Z}}$, or $\mathrm{PVY}^{\mathrm{N}}$ obtained from cultivated potato in 1943 to 1984 were sequenced. None of the

or $\mathrm{PVY} \mathrm{Yu}^{\mathrm{Eu}}\left(\mathrm{Y}^{\mathrm{N}}-\mathrm{RM}\right)$, Australian isolate $\mathrm{Y}^{\mathrm{O}}-\mathrm{BL} 2$ was in minor phylogroup $\mathrm{PVY}^{\mathrm{O}-\mathrm{O} 5}$, and both Mexican isolate $\mathrm{Y}^{\mathrm{N}}-\mathrm{Mex} 43$ and U.S.A. isolates $\mathrm{Y}^{\mathrm{N}}$-MT12_Oth288, $\mathrm{Y}^{\mathrm{N}}-\mathrm{MT} 12$-Oth295, and $\mathrm{Y}^{\mathrm{N}}$ WWAA150131G42 were in minor phylogroup PVY ${ }^{\mathrm{Eu}-\mathrm{N}}$. When combined, these new findings and those from the eight historical UK isolates sequenced earlier provide important historical insights concerning the diversity of early PVY populations in Europe and the appearance of recombinants in that part of the world. They and four recent Australian isolates sequenced earlier also provide geographical insights about the geographical distribution and diversity of PVY populations in Australia and North America.
\end{abstract} nine complete PVY genomes obtained were recombinants. Phylogenetic analysis revealed that the four historical UK isolates were in minor phylogroups $\mathrm{PVY}^{\mathrm{C} 1}\left(\mathrm{Y}^{\mathrm{C}}-\mathrm{R}\right), \mathrm{PVY}^{\mathrm{O}-\mathrm{O}}\left(\mathrm{Y}^{\mathrm{Z}}-\mathrm{CM} 1\right), \mathrm{PVY}^{\mathrm{NA}-\mathrm{N}}\left(\mathrm{Y}^{\mathrm{N}}-\mathrm{M}\right)$,
Keywords: potato virus Y, pathogen diversity, potato, historical isolates, biological strain groups, phylogenetics
Potato (Solanum tuberosum) is one of the world's most important food crops (FAOSTAT 2017), and potato virus Y (PVY; family Potyviridae, genus Potyvirus) currently causes the most important virus disease of potato worldwide. It gives rise to substantial losses in potato tuber yield, reduces tuber quality by causing potato tuber necrotic ringspot disease (PTNRD) in PVY-sensitive cultivars, and disrupts healthy seed potato production (Gray et al. 2010; Jones 2014; Karasev and Gray 2013a; Kreuze et al. 2020; Singh et al. 2008; Valkonen 2007). It has a single stranded, positive sense RNA genome of $\sim 9.7 \mathrm{~kb}$, is nonpersistently aphid-transmitted (Karasev and Gray 2013a; Kerlan 2006), and is also contact-transmissible (Coutts and Jones 2015). In addition, PVY causes economically important diseases in other solanaceous crops, especially tobacco, tomato, and pepper (Blanchard

${ }^{\dagger}$ Corresponding authors: A. V. Karasev, akarasev@uidaho.edu; and R. A. C. Jones, roger.jones@uwa.edu.au

Funding: This work was funded in part through grants from USDA-NIFANRI (2009-35600-05025), USDA-NIFA-SCRI (2014-51181-22373), USDANIFA-Hatch (project IDA01560), USDA-ARS (58-8042-6-049), Idaho State Department of Agriculture, Northwest Potato Research Consortium, Idaho Potato Commission, Washington State Potato Commission, and by the Idaho Agricultural Experiment Station.

*The $\boldsymbol{e}$-Xtra logo stands for "electronic extra" and indicates that one supplementary table is published online.

The author(s) declare no conflict of interest.

Accepted for publication 26 March 2020.

(c) 2020 The American Phytopathological Society et al. 2008; Green et al. 2017b; Kehoe and Jones 2016; Kerlan 2006; Kerlan and Moury 2008; Moury 2010; Quenouille et al. 2013).

Biological strain groups consisting of PVY isolates from potato are distinguished by whether they elicit hypersensitive responses (HR) in potato cultivar differentials carrying hypersensitivity genes or systemic veinal necrosis symptoms in tobacco. Strain groups $\mathrm{PVY}^{\mathrm{C}}, \mathrm{PVY}^{\mathrm{O}}$, and $\mathrm{PVY}^{\mathrm{Z}}$ elicit HR phenotypes with hypersensitivity genes $N c, N y$, or $N z$, respectively. Strain groups $\mathrm{PVY}^{\mathrm{N}}$ and $\mathrm{PVY}{ }^{\mathrm{E}}$ overcome all three, but differ in the phenotypes they induce in tobacco, with only $\mathrm{PVY}^{\mathrm{N}}$ eliciting veinal necrosis (Chikh-Ali et al. 2014; Cockerham 1970; Jones 1990; Karasev and Gray 2013a, b; Kehoe and Jones 2016; Kerlan et al. 2011; Rowley et al. 2015; Singh et al. 2008). Previously, biological strain groups $\mathrm{PVY}^{\mathrm{C}}$ and $\mathrm{PVY} \mathrm{Y}^{\mathrm{O}}$ were thought to coincide with major phylogroups $\mathrm{PVY}^{\mathrm{C}}$ and $\mathrm{PVY}$, respectively (Boonham et al. 2002; Moury et al. 2002). However, this proved incorrect as isolates within biological strain groups $\mathrm{PVY}^{\mathrm{Z}}$ and new strain group $\mathrm{PVY}^{\mathrm{D}}$ fitted within major phylogroups $\mathrm{PVY} \mathrm{Y}^{\mathrm{O}}$ and PVYC ${ }^{\mathrm{C}}$, respectively (Kehoe and Jones 2016). As the number of complete PVY genome sequences from different world regions grows, phylogenetic nomenclature based on biological, geographical, and sequence names is becoming increasingly unsustainable so substituting Latinized numerals for current phylogroup names was suggested (Jones 2014; Jones and Kehoe 2016; Kehoe and Jones 2016). When Gibbs et al. (2017) examined the phylogenetics of the global population of PVY isolates with complete genomes, $42 \%$ were nonrecombinants and $58 \%$ recombinants. The nonrecombinants were all within major phylogroups $\mathrm{PVY}^{\mathrm{C}}, \mathrm{PVY}^{\mathrm{N}}$, or $\mathrm{PVY}^{\mathrm{O}}$, while recombinants between $\mathrm{PVY} \mathrm{N}^{\mathrm{N}}$ and $\mathrm{PVY} \mathrm{Y}^{\mathrm{O}}$ were in major phylogroups R-1 or R-2. The principal parents of R-1 and R-2 were $\mathrm{PVY}^{\mathrm{N}}$ or $\mathrm{PVY}^{\mathrm{O}}$, respectively, and vice versa for their secondary parents. The minor phylogroups within these major phylogroups [numerals from PVY classification 
Table 1. Isolates of potato virus $Y$ sequenced in this study, or by the authors listed

\begin{tabular}{|c|c|c|c|c|c|c|c|c|c|}
\hline Isolate & $\begin{array}{c}\text { Biological } \\
\text { strain } \\
\text { group }\end{array}$ & $\begin{array}{l}\text { Phylogroup (this } \\
\text { study or Kehoe } \\
\text { and Jones 2016) }\end{array}$ & $\begin{array}{c}\text { Original } \\
\text { host }\end{array}$ & $\begin{array}{c}\text { Year } \\
\text { isolated }\end{array}$ & $\begin{array}{c}\text { Geographical } \\
\text { origin }\end{array}$ & $\begin{array}{l}\text { First isolate } \\
\text { reference }\end{array}$ & $\begin{array}{c}\text { Strain } \\
\text { group } \\
\text { reference }\end{array}$ & $\begin{array}{l}\text { CP accession no. } \\
\text { (Kehoe and Jones } \\
\text { 2011) }\end{array}$ & $\begin{array}{c}\text { Genome accession } \\
\text { no. from this } \\
\text { study or Kehoe } \\
\text { and Jones (2016) }\end{array}$ \\
\hline \multicolumn{10}{|c|}{ Historical isolates sequenced in this study } \\
\hline $\mathrm{R}$ & $\mathrm{Y}^{\mathrm{C}}$ & $\mathrm{Y}^{\mathrm{C} 1}$ & $\begin{array}{l}\text { Potato cv. } \\
\text { Edgecote } \\
\text { Purple }\end{array}$ & 1943 & $\begin{array}{l}\text { United } \\
\text { Kingdom }\end{array}$ & $\begin{array}{l}\text { Bawden and } \\
\text { Kassanis } \\
(1947)\end{array}$ & $\begin{array}{l}\text { Jones } \\
\text { (1990) }\end{array}$ & JN034578 & MT200665 \\
\hline $\mathrm{RM}$ & $\mathrm{Y}^{\mathrm{N}}$ & $\mathrm{Y}^{\mathrm{NA}-\mathrm{N}}$ & $\begin{array}{l}\text { Potato cv. } \\
\text { Record }\end{array}$ & 1981 & $\begin{array}{l}\text { Terrington, } \\
\text { England }\end{array}$ & $\begin{array}{l}\text { Jones } \\
(1990)\end{array}$ & $\begin{array}{l}\text { Jones } \\
\text { (1990) }\end{array}$ & - & MT200666 \\
\hline M & $\mathrm{Y}^{\mathrm{N}}$ & $\mathrm{Y}^{\mathrm{Eu}-\mathrm{N}}$ & $\begin{array}{l}\text { Potato cv. } \\
\text { unknown }\end{array}$ & $<1983$ & Unknown & $\begin{array}{l}\text { Jones } \\
\text { (1990) }\end{array}$ & $\begin{array}{l}\text { Jones } \\
\text { (1990) }\end{array}$ & - & MT200667 \\
\hline CM1 & $\mathrm{Y}^{\mathrm{Z}}$ & $\mathrm{Y}^{\mathrm{O}-\mathrm{O}}$ & $\begin{array}{l}\text { Potato cv. } \\
\text { Cara }\end{array}$ & 1981 & $\begin{array}{l}\text { Cambridge, } \\
\text { England }^{\mathrm{a}}\end{array}$ & $\begin{array}{l}\text { Jones } \\
(1990)\end{array}$ & $\begin{array}{l}\text { Jones } \\
(1990)\end{array}$ & - & MT200668 \\
\hline \multicolumn{10}{|c|}{ Recent isolates sequenced in this study } \\
\hline BL2 & - & $\mathrm{Y}^{\mathrm{O}-\mathrm{O} 5}$ & $\begin{array}{l}\text { Potato cv. } \\
\text { Bliss }\end{array}$ & 2014 & $\begin{array}{l}\text { Pemberton, } \\
\text { Western } \\
\text { Australia }\end{array}$ & This study & - & - & MT200669 \\
\hline Mex43 & - & $\mathrm{Y}^{\mathrm{Eu}-\mathrm{N}}$ & $\begin{array}{l}\text { Wild } \\
\text { Solanum } \\
\text { sp. }\end{array}$ & 2014 & $\begin{array}{l}\text { Jalisco, } \\
\text { Mexico }\end{array}$ & This study & - & - & MT200670 \\
\hline MT12_Oth288 & - & $\mathrm{Y}^{\mathrm{Eu}-\mathrm{N}}$ & $\begin{array}{l}\text { Potato cv. } \\
\text { Ranger } \\
\text { Russet }\end{array}$ & 2012 & $\begin{array}{l}\text { Washington, } \\
\text { U.S.A. }\end{array}$ & This study & - & - & MT200671 \\
\hline MT12_Oth295 & - & $\mathrm{Y}^{\mathrm{Eu}-\mathrm{N}}$ & $\begin{array}{l}\text { Potato cv. } \\
\text { Ranger } \\
\text { Russet }\end{array}$ & 2012 & $\begin{array}{l}\text { Washington, } \\
\text { U.S.A. }\end{array}$ & This study & - & - & MT200672 \\
\hline $\begin{array}{l}\text { WWA150131_ } \\
\text { G4_8 }\end{array}$ & - & $\mathrm{Y}^{\mathrm{Eu}-\mathrm{N}}$ & $\begin{array}{l}\text { Potato cv. } \\
\text { Chieftan }\end{array}$ & 2015 & $\begin{array}{l}\text { Washington, } \\
\text { U.S.A. }\end{array}$ & This study & - & - & MT200673 \\
\hline \multicolumn{10}{|c|}{ Historical isolates already with complete genome sequences } \\
\hline $\mathrm{Y}^{\mathrm{C}}-\mathrm{CT}$ & $\mathrm{Y}^{\mathrm{C}}$ & $\mathrm{Y}^{\mathrm{C} 2}$ & $\begin{array}{l}\text { Potato cv. } \\
\text { Catriona }\end{array}$ & $<1980$ & $\begin{array}{l}\text { United } \\
\text { Kingdom }\end{array}$ & $\begin{array}{l}\text { Jones } \\
(1990)\end{array}$ & $\begin{array}{l}\text { Jones } \\
(1990)\end{array}$ & JN034577 & KP691324 \\
\hline $\mathrm{Y}^{\mathrm{C}}-\mathrm{CRM} 1$ & $\mathrm{Y}^{\mathrm{C}}$ & $\mathrm{Y}^{\mathrm{C} 2}$ & $\begin{array}{l}\text { Potato cv. } \\
\text { Pentland } \\
\text { Crown }\end{array}$ & 1982 & $\begin{array}{l}\text { Cambridge, } \\
\text { England }^{\mathrm{a}}\end{array}$ & $\begin{array}{l}\text { Jones } \\
\text { (1990) }\end{array}$ & $\begin{array}{l}\text { Jones } \\
\text { (1990) }\end{array}$ & JN034576 & KP691321 \\
\hline $\mathrm{Y}^{\mathrm{O}}-\mathrm{CRN}$ & $\mathrm{Y}^{\mathrm{O}}$ & $\mathrm{Y}^{\mathrm{O}-\mathrm{O}}$ & $\begin{array}{l}\text { Potato cv. } \\
\text { Pentland } \\
\text { Crown }\end{array}$ & 1982 & $\begin{array}{l}\text { Cambridge, } \\
\text { England }^{\mathrm{a}}\end{array}$ & $\begin{array}{l}\text { Jones } \\
\text { (1990) }\end{array}$ & $\begin{array}{l}\text { Jones } \\
\text { (1990) }\end{array}$ & JN034573 & KP691323 \\
\hline $\mathrm{Y}_{-}^{\mathrm{O}} \mathrm{KE}$ & $\mathrm{Y}^{\mathrm{O}}$ & $\mathrm{Y}^{\mathrm{O}-\mathrm{O}}$ & $\begin{array}{l}\text { Potato cv. } \\
\text { King } \\
\text { Edward }\end{array}$ & 1943 & $\begin{array}{l}\text { United } \\
\text { Kingdom }\end{array}$ & $\begin{array}{l}\text { Bawden and } \\
\text { Kassanis } \\
(1947)\end{array}$ & $\begin{array}{l}\text { Jones } \\
(1990)\end{array}$ & JN034571 & KP691327 \\
\hline $\mathrm{Y}^{\mathrm{O}}-\mathrm{RS}$ & $\mathrm{Y}^{\mathrm{O}}$ & $\mathrm{Y}^{\mathrm{O}-\mathrm{O}}$ & $\begin{array}{l}\text { Potato cv. } \\
\text { Record }\end{array}$ & 1981 & $\begin{array}{l}\text { Terrington, } \\
\text { England }\end{array}$ & $\begin{array}{l}\text { Jones } \\
(1990)\end{array}$ & $\begin{array}{l}\text { Jones } \\
(1990)\end{array}$ & JN034574 & KР691330 \\
\hline $\mathrm{Y}^{\mathrm{Z}}-\mathrm{CM} 2$ & $\mathrm{Y}^{\mathrm{Z}}$ & $\mathrm{Y}^{\mathrm{O}-\mathrm{O}}$ & $\begin{array}{l}\text { Potato cv. } \\
\text { Cara }\end{array}$ & 1984 & $\begin{array}{l}\text { Cambridge, } \\
\text { England }^{\mathrm{a}}\end{array}$ & $\begin{array}{l}\text { Jones } \\
(1990)\end{array}$ & $\begin{array}{l}\text { Jones } \\
(1990)\end{array}$ & JN034572 & KP691319 \\
\hline $\mathrm{Y}^{\mathrm{Z}}-\mathrm{CRM} 2$ & $\mathrm{Y}^{\mathrm{Z}}$ & $\mathrm{Y}^{\mathrm{O}-\mathrm{O}}$ & $\begin{array}{l}\text { Potato cv. } \\
\text { Pentland } \\
\text { Crown }\end{array}$ & 1982 & $\begin{array}{l}\text { Cambridge, } \\
\text { England }^{\mathrm{a}}\end{array}$ & $\begin{array}{l}\text { Jones } \\
(1990)\end{array}$ & $\begin{array}{l}\text { Jones } \\
(1990)\end{array}$ & JN034568 & KР691322 \\
\hline $\mathrm{Y}^{\mathrm{Z}}-\mathrm{DS}$ & $\mathrm{Y}^{\mathrm{Z}}$ & $\mathrm{Y}^{\mathrm{O}-\mathrm{O}}$ & $\begin{array}{l}\text { Potato cv. } \\
\text { Desiree }\end{array}$ & 1984 & $\begin{array}{l}\text { Cambridge, } \\
\text { England }\end{array}$ & $\begin{array}{l}\text { Jones } \\
\text { (1990) }\end{array}$ & $\begin{array}{l}\text { Jones } \\
\text { (1990) }\end{array}$ & JN034569 & KP691326 \\
\hline \multicolumn{10}{|c|}{ More contemporary isolates already with complete genome sequences } \\
\hline $\mathrm{CN} 1$ & - & $\mathrm{Y}^{\mathrm{C} 1}$ & $\begin{array}{l}\text { Tomato cv. } \\
\text { unknown }\end{array}$ & 2006 & $\begin{array}{l}\text { Carnarvon, } \\
\text { Western } \\
\text { Australia }\end{array}$ & $\begin{array}{l}\text { Kehoe and } \\
\text { Jones } \\
(2011)\end{array}$ & $\begin{array}{l}\text { Kehoe } \\
\text { and Jones } \\
(2016)\end{array}$ & JN034579 & KP691320 \\
\hline $\mathrm{KIP} 1^{\mathrm{b}}$ & $\mathrm{Y}^{\mathrm{D}}$ & $\mathrm{Y}^{\mathrm{C} 2}$ & $\begin{array}{l}\text { Potato cv. } \\
\text { Kipfler }\end{array}$ & 2008 & $\begin{array}{l}\text { Queensland, } \\
\text { Australiab }^{\text {b }}\end{array}$ & $\begin{array}{l}\text { Kehoe and } \\
\text { Jones } \\
(2016)\end{array}$ & $\begin{array}{l}\text { Kehoe } \\
\text { and Jones } \\
(2016)\end{array}$ & - & KР691329 \\
\hline BL & $\mathrm{Y}^{\mathrm{O}}$ & $\mathrm{Y}^{\mathrm{O}-\mathrm{O} 5}$ & $\begin{array}{l}\text { Potato cv. } \\
\text { Bliss }\end{array}$ & 2003 & $\begin{array}{l}\text { Busselton, } \\
\text { Western } \\
\text { Australia }\end{array}$ & $\begin{array}{l}\text { Kehoe and } \\
\text { Jones } \\
(2011)\end{array}$ & $\begin{array}{l}\text { Kehoe } \\
\text { and Jones } \\
(2016)\end{array}$ & JN034575 & KР691318 \\
\hline DEL3 & $\mathrm{Y}^{\mathrm{O}}$ & $\mathrm{Y}^{\mathrm{O}-\mathrm{O} 5}$ & $\begin{array}{l}\text { Potato cv. } \\
\text { Delaware }\end{array}$ & 2011 & $\begin{array}{l}\text { Manjimup, } \\
\text { Western } \\
\text { Australia }\end{array}$ & $\begin{array}{l}\text { Kehoe and } \\
\text { Jones } \\
(2011)\end{array}$ & $\begin{array}{l}\text { Kehoe } \\
\text { and Jones } \\
(2016)\end{array}$ & JN034566 & KP691325 \\
\hline & & & & & & & & \multicolumn{2}{|c|}{ (Continued on next page) } \\
\hline
\end{tabular}

${ }^{\text {a }}$ From National Institute of Agricultural Botany plots, Cambridge, England.

$\mathrm{b}$ Isolate from shop purchased potato tubers originally from Queensland, Australia. 
Table 1. (Continued from previous page)

\begin{tabular}{|c|c|c|c|c|c|c|c|c|c|}
\hline Isolate & $\begin{array}{c}\text { Biological } \\
\text { strain } \\
\text { group }\end{array}$ & $\begin{array}{l}\text { Phylogroup (this } \\
\text { study or Kehoe } \\
\text { and Jones 2016) }\end{array}$ & $\begin{array}{l}\text { Original } \\
\text { host }\end{array}$ & $\begin{array}{c}\text { Year } \\
\text { isolated }\end{array}$ & $\begin{array}{c}\text { Geographical } \\
\text { origin }\end{array}$ & $\begin{array}{c}\text { First isolate } \\
\text { reference }\end{array}$ & $\begin{array}{c}\text { Strain } \\
\text { group } \\
\text { reference }\end{array}$ & $\begin{array}{l}\text { CP accession no. } \\
\text { (Kehoe and Jones } \\
\text { 2011) }\end{array}$ & $\begin{array}{c}\text { Genome accession } \\
\text { no. from this } \\
\text { study or Kehoe } \\
\text { and Jones (2016) }\end{array}$ \\
\hline ATL1 & $\mathrm{Y}^{\mathrm{Z}}$ & $\mathrm{Y}^{\mathrm{O}-\mathrm{O} 5}$ & $\begin{array}{l}\text { Potato cv. } \\
\text { Atlantic }\end{array}$ & 2012 & $\begin{array}{l}\text { Manjimup, } \\
\text { Western } \\
\text { Australia }\end{array}$ & $\begin{array}{l}\text { Kehoe and } \\
\text { Jones } \\
(2016)\end{array}$ & $\begin{array}{l}\text { Kehoe } \\
\text { and Jones } \\
(2016)\end{array}$ & - & KP691317 \\
\hline NE38 & - & $\mathrm{Y}^{\mathrm{O}-\mathrm{O}}$ & $\begin{array}{l}\text { Potato cv. } \\
\text { unknown }\end{array}$ & 2004 & $\begin{array}{l}\text { Nebraska, } \\
\text { U.S.A. }\end{array}$ & $\begin{array}{l}\text { Green et al. } \\
(2017 a)\end{array}$ & $\begin{array}{l}\text { Green } \\
\text { et al. } \\
(2017 a)\end{array}$ & - & KY848004 \\
\hline ME_236_120 & - & $\mathrm{Y}^{\mathrm{O}-\mathrm{O}}$ & $\begin{array}{l}\text { Potato cv. } \\
\text { unknown }\end{array}$ & 2004 & Maine, U.S.A. & $\begin{array}{l}\text { Green et al. } \\
(2017 a)\end{array}$ & $\begin{array}{l}\text { Green } \\
\text { et al. } \\
(2017 a)\end{array}$ & - & KY847962 \\
\hline NY100003 & - & $\mathrm{Y}^{\mathrm{O}-\mathrm{O}}$ & $\begin{array}{l}\text { Potato cv. } \\
\text { unknown }\end{array}$ & 2010 & $\begin{array}{l}\text { New York, } \\
\text { U.S.A. }\end{array}$ & $\begin{array}{l}\text { Green et al. } \\
(2017 a)\end{array}$ & $\begin{array}{l}\text { Green } \\
\text { et al. } \\
(2017 a)\end{array}$ & - & KY848012 \\
\hline SASA-110 & - & $\mathrm{Y}^{\mathrm{O}-\mathrm{O}}$ & $\begin{array}{l}\text { Potato cv. } \\
\text { unknown }\end{array}$ & 2004 & $\begin{array}{l}\text { United } \\
\text { Kingdom }\end{array}$ & $\begin{array}{l}\text { Barker et al. } \\
(2009)\end{array}$ & $\begin{array}{l}\text { Barker } \\
\text { et al. } \\
(2009)\end{array}$ & - & AJ585195 \\
\hline O-139 & $\mathrm{Y}^{\mathrm{O}}$ & $\mathrm{Y}^{\mathrm{O}-\mathrm{O} 5}$ & $\begin{array}{l}\text { Potato cv. } \\
\text { unknown }\end{array}$ & 1993 & $\begin{array}{l}\text { Eastern } \\
\text { Canada }\end{array}$ & $\begin{array}{l}\text { Singh and } \\
\text { Singh } \\
(1996)\end{array}$ & $\begin{array}{l}\text { Singh and } \\
\text { Singh } \\
(1996)\end{array}$ & - & U09509 \\
\hline ME120 & - & $\mathrm{Y}^{\mathrm{O}-\mathrm{O}}$ & $\begin{array}{l}\text { Potato cv. } \\
\text { unknown }\end{array}$ & 2005 & Maine, U.S.A. & $\begin{array}{l}\text { Karasev } \\
\text { et al. (2011) }\end{array}$ & $\begin{array}{l}\text { Karasev } \\
\text { et al. } \\
(2011)\end{array}$ & - & HQ912892 \\
\hline ME236_4 & - & $\mathrm{Y}^{\mathrm{O}-\mathrm{O}}$ & $\begin{array}{l}\text { Potato cv. } \\
\text { unknown }\end{array}$ & 2004 & Maine, U.S.A. & $\begin{array}{l}\text { Karasev } \\
\text { et al. }(2011)\end{array}$ & $\begin{array}{l}\text { Karasev } \\
\text { et al. } \\
(2011)\end{array}$ & - & HQ912891 \\
\hline
\end{tabular}

system of Kehoe and Jones (2016) in parentheses] were: C with $\mathrm{C} 1$ (II) and $\mathrm{C} 2(\mathrm{III})$; $\mathrm{O}$ with $\mathrm{O}(=\mathrm{I})$ and $\mathrm{O} 5(=\mathrm{X}) ; \mathrm{N}$ with $\mathrm{Eu}-\mathrm{N}$ (= IV), XIII, and NA-N (= IX); R-1 with SYR-I (XII), NTN-B (VI), SYR-II (XI), N-Wi (VII), and N:O (VIII); and R-2 with NTN-A (V) (Gibbs et al. 2017).

Kehoe and Jones (2016) compared the biological and complete genome properties of eight historical UK (1943 to 1984) and five Australian (2003 to 2012) PVY isolates, none of which were recombinants. The UK isolates belonged to biological strain groups $\mathrm{PVY}^{\mathrm{C}}, \mathrm{PVY}^{\mathrm{O}}$, or $\mathrm{PVY}^{\mathrm{Z}}$ (Jones 1990), and the Australian isolates to $\mathrm{PVY}^{\mathrm{O}}, \mathrm{PVY}^{\mathrm{Z}}$, or new strain group $\mathrm{PVY}^{\mathrm{D}}$, which elicited putative hypersensitivity gene $N d$; the tomato isolates were left ungrouped as they proved poorly adapted to infect potato systemically (Kehoe and Jones 2016). Putative gene $N d$ was present in all but three of 39 Australasian, European, or North American potato cultivars (Jones and Vincent 2018). On phylogenetic analysis of complete genomes, the Australian PVY isolates from potato were in minor phylogroups $\mathrm{Y}^{\mathrm{O}-\mathrm{O}}, \mathrm{Y}^{\mathrm{O}-\mathrm{O} 5}$, or $\mathrm{Y}^{\mathrm{C} 2}$, the Australian tomato isolate sequenced was in minor phylogroup $\mathrm{Y}^{\mathrm{Cl}}$, and the historical $\mathrm{UK}$ potato isolates were in $\mathrm{Y}^{\mathrm{O}-\mathrm{O}}$ or $\mathrm{Y}^{\mathrm{C} 2}$. Moreover, biologically defined $\mathrm{PVY}^{\mathrm{O}}$ and $\mathrm{PVY}^{\mathrm{Z}}$ isolates were within $\mathrm{Y}^{\mathrm{O}-\mathrm{O}}$ or $\mathrm{Y}^{\mathrm{O}-\mathrm{O} 5}, \mathrm{PVY}^{\mathrm{C}}$ isolates within $\mathrm{Y}^{\mathrm{C} 2}, \mathrm{PVY}^{\mathrm{D}}$ within $\mathrm{Y}^{\mathrm{C} 2}$, and the tomato isolate in $\mathrm{Y}^{\mathrm{C} 1}$. In the present study, whole genomes were obtained of four additional historical UK isolates from strain groups $\mathrm{PVY}$, $\mathrm{PVY}^{\mathrm{N}}$, or PVY $\mathrm{Z}^{\mathrm{Z}}$ previously studied by Jones (1990). They were compared with (i) the eight historical UK and four recent Australian PVY isolates sequenced by Kehoe and Jones (2016), (ii) five modern nonrecombinant PVY isolates collected in Australia, Mexico, or the United States, and (iii) other nonrecombinant isolates from GenBank.

Four PVY isolates were obtained from freeze dried specimens kept in Perth, Western Australia since importation from England in 1986 under an Australian quarantine permit (Table 1). They had been freeze-dried in sealed glass ampoules from fresh infected potato or tobacco leaf tissue in 1984 and never revived thereafter. Isolate $\mathrm{Y}^{\mathrm{C}}-\mathrm{R}$ was the classical Rothamsted PVYC isolate obtained in 1943 from cv. Edgecotte Purple (Bawden and Kassanis 1946, 1947; Kassanis and Govier 1971). Isolates $\mathrm{Y}^{\mathrm{N}}-\mathrm{RM}$ and $\mathrm{Y}^{\mathrm{Z}}-\mathrm{CM} 1$ were obtained in 1981 from cv. Record growing at Terrington, Norfolk, England, or cv. Cara growing at Cambridge, England, respectively. Isolate $\mathrm{Y}^{\mathrm{N}}-\mathrm{M}$ was from the UK in the early 1980s (cultivar and location not recorded). Before freeze drying in England, these four isolates were maintained by subculture in tobacco plants (cv. White Burley) or replanting infected potato tubers (Jones 1990). Their biological properties were reported previously (Jones 1990). In October 2015, single glass ampoules containing each historical PVY isolate were broken in Australia where dry leaf tissue from each of them (approximately $0.5 \mathrm{~g}$ ) was transferred into a sterile mortar for homogenization with $0.5 \mathrm{ml} 0.1 \mathrm{M}$ phosphate-buffered saline ( $\mathrm{pH} 7.2$ ). New isolate BL2 obtained in 2014 from potato cv. Bliss growing at Pemberton, Western Australia, during routine seed potato testing by ELISA was maintained thereafter in tobacco cv. White Burley. It was extracted from a fresh infected tobacco leaf in the same way. With each isolate, the resulting homogenate was applied to PlantSaver FTA Cards (Whatman), followed by drying and sealing in plastic bags. The five FTA cards were transported to the University of Idaho (UI), U.S.A., for further characterization. Isolate Mex43, collected during a survey of seed potato lots in 2014 at Tapalpa, Jalisco, Mexico, came from an asymptomatic wild Solanum spp. weed growing in a service road alongside a potato field. The sample, which tested positive for PVY using an immuno-strip test (Agdia, Elkhart, IN), was pressed onto a PlantSaver FTA Card (Whatman) and sent to UI as described above. Isolates MT12_Oth288 and MT12_Oth295 were collected in 2012 from infected cv. Ranger Russet plants growing in two commercial potato seed lots planted with seed tubers originally from Montana and being grown at Othello, Washington State (WA). Isolate WWA150131_G4_ 8 was collected in 2015 from a cv. Chieftain plant growing in a winter grow-out test in western WA, U.S.A. After initial typing using ELISA (Nikolaeva et al. 2012) and RT-PCR (Chikh-Ali et al. 2013; Lorenzen et al. 2006), these three isolates were cultured in tobacco cv. White Burley. Several reference PVY isolates from the UI collection belonging to nonrecombinant major phylogroup $\mathrm{PVY}^{\mathrm{C}}$, and minor phylogroups $\mathrm{PVY}^{\mathrm{O}-\mathrm{O}}, \mathrm{PVY}^{\mathrm{O}-\mathrm{O} 5}, \mathrm{PVY}^{\mathrm{Eu}-\mathrm{N}}$, and PVY ${ }^{\mathrm{NA}-\mathrm{N}}$ were used for comparisons as described previously (Chikh-Ali et al. 2013; Funke et al. 2017; Green et al. 2017b; Nikolaeva et al. 2012).

RNA was extracted from FTA cards as described by Ndunguru et al. (2005). The resulting RNA pellets were dissolved in $30 \mu \mathrm{l}$ nuclease-free water, heated at $65^{\circ} \mathrm{C}$ for $5 \mathrm{~min}$, and then chilled on ice for $3 \mathrm{~min}$. Total nucleic acids were extracted from infected potato 
and tobacco leaves as described previously (Dellaporta et al. 1983; Green et al. 2017a; Hu et al. 2009). They were typed using two different multiplex RT-PCR assays as described by Lorenzen et al. (2006) and Chikh Ali et al. (2010). Reverse transcription and PCR reactions were as described previously (Chikh-Ali et al. 2013; Green et al. 2017a). Control PVY isolates from the UI laboratory collection were used, and the assays on infected samples involved immunocapture RT-PCR (Chikh-Ali et al. 2013).

Serological reactivity of WWA150131_G4_8, MT12_Oth288, and MT12_Oth295 was tested by TAS-ELISA (Nikolaeva et al. 2012); all such tests included control PVY isolates with serological patterns characteristic of $\mathrm{PVY}^{\mathrm{O}-\mathrm{O}}, \mathrm{PVY}^{\mathrm{N}}$, and $\mathrm{PVY}{ }^{\mathrm{O}-\mathrm{O} 5}$. A polyclonal PVY antiserum and four phylogroup specific monoclonal antibodies were used: SASA-O recognizing $\mathrm{PVY} \mathrm{Y}^{\mathrm{O}-\mathrm{O}}, \mathrm{PVY}^{\mathrm{O}-\mathrm{O}}$,

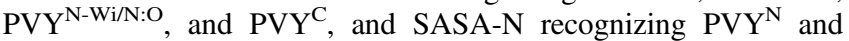
$\mathrm{PVY}^{\mathrm{NTN}}$ (SASA, Scottish Agriculture Science Agency, Edinburgh, Scotland); and 1F5 (Agdia, Elkhart, IN) recognizing $\mathrm{PVY}^{\mathrm{N}}$, $\mathrm{PVY}^{\mathrm{O}-\mathrm{O} 5}$, and PVY ${ }^{\mathrm{NTN}}$ (Funke et al. 2017; Karasev et al. 2010).

Nearly whole genome sequences were obtained by sequencing overlapping RT-PCR products as described by Green et al. (2017a); due to the sequencing methodology used, $100 \mathrm{nt}$ of the terminal $5^{\prime}$ end remained unsequenced. The sequencing strategy of Green et al. (2017a) involved direct sequencing of RT-PCR fragments generated by 48 primer pairs that amplified nearly the whole PVY genome. All PCR products were purified using the ExoSAPIT for PCR Product Clean-Up (USB Products; Affymetrix Inc.), mixed with appropriate primers and submitted to Genewiz, Inc. (South Plainfield, NJ) for Sanger sequencing. These PCR products provided good sequence overlap, resulting in at least fourfold coverage of each PVY genome that represented a consensus; no genetic heterogeneity was present in the samples. The contigs obtained were assembled using the SeqMan Pro program of the Lasergene 9 Suite (DNASTAR). For multiple sequence alignments, MUSCLE (Edgar 2004) implemented in MEGA version 7 (Tamura et al. 2013) was used with default parameters. The alignment consisted of all nine newly sequenced isolates listed in Table 1 . Sequence identity was checked using BLAST provided by the National Center for Biotechnology Information (NCBI) (Altschul et al. 1990). The aligned sequences were checked for recombination, using RDP (Martin and Rybicki 2000), GENECONV (Sawyer 1999), BOOTSCAN (Salminen et al. 1995), MAXCHI (Maynard-Smith 1992), CHIMAERA (Posada and Crandall 2001), 3Seq (Boni et al. 2007), and SiScan (Gibbs et al. 2000) methods in RDP4 v4.61 software (Martin et al. 2005). This recombination analysis was conducted as described by Green et al. (2017a), with an isolate considered recombinant if all six programs of the RDP package (RDP, GENCONV, Chimaera, MaxChi, Bootscan, SiScan) had significant support $(P<0.0001)$. Phylogeny inference based on whole genomes was by the maximum likelihood (ML) method implemented in MEGA 7. Bidens mosaic virus sequence (KF649336; Sanches et al. 2014) was used as an outgroup. Phylogroup diversity within and between nonrecombinant isolates was calculated using MEGA 7 (Tamura et al. 2013).
Prior to freeze-drying, historical UK isolates $\mathrm{Y}^{\mathrm{N}}-\mathrm{M}, \mathrm{Y}^{\mathrm{N}}-\mathrm{RM}, \mathrm{Y}^{\mathrm{C}}$ $\mathrm{R}$, and $\mathrm{Y}^{\mathrm{Z}}{ }_{-\mathrm{CM}} 1$ had all been inoculated to plants of PVY differential potato cultivars and tobacco which established their biological strain groups (Jones 1990). When inoculated to tobacco plants, new isolates WWA150131_G4_8, MT12_Oth288, and MT12_Oth295 all caused systemic veinal necrosis typical of strain group $\mathrm{PVY}^{\mathrm{N}}$, but isolate BL2 caused a systemic mosaic so was not PVY ${ }^{\mathrm{N}}$ (Table 2). Due to regulatory restrictions for introduction of pathogens to the U.S.A., isolate Mex 43 could not be characterized biologically from FTA cards.

Based on ELISA results, the three PVY isolates from the U.S.A. had N-serotype, and all three were typed as PVYEu-N based on RTPCR (Table 2). Isolates Mex43 and $\mathrm{Y}^{\mathrm{N}}-\mathrm{M}$ analyzed from FTA cards produced two characteristic bands, 328 and $398 \mathrm{bp}$, in the RT-PCR multiplex assay of Lorenzen et al. (2006), and three bands, 398, 633, and 1,307 bp, in the RT-PCR multiplex assay of Chikh-Ali et al. (2010). Therefore, they also belonged to PVY ${ }^{\mathrm{Eu}-\mathrm{N}}$, as did control isolate N605. By contrast, isolate $\mathrm{Y}^{\mathrm{N}}-\mathrm{RM}$ produced a single 328-bp band in the Lorenzen assay and a single 1,307-bp band in the Chikh-Ali assay, so it belonged to PVY ${ }^{\mathrm{NA}-\mathrm{N}}$, as did control isolate RRA1. Isolates $\mathrm{Y}^{\mathrm{Z}}{ }_{-} \mathrm{CM} 1$ and BL2 produced two characteristic bands, 267 and $689 \mathrm{bp}$, in the Lorenzen assay, and 532 and 853 bp bands in the Chikh-Ali assay, so belonged to $\mathrm{PVY}^{\mathrm{O}}$, like control isolate $\mathrm{Oz}$. Isolate $\mathrm{Y}^{\mathrm{C}}-\mathrm{R}$ produced no bands in either Lorenzen or Chikh-Ali RT-PCR assays, resembling PVYC isolates (Chikh-Ali et al. 2016; Green et al. 2017b).

Nearly complete, ca. $9.6 \mathrm{~kb}$ genomes of all nine isolates were deposited in the GenBank database under accession numbers MT200665 to MT200673 (Table 1). A single, 3,061-aa polyprotein was encoded by a single open reading frame (ORF) in each of their sequences. A short ORF called PIPO (Chung et al. 2008) was also present within their P3 cistrons. Sequence identity levels differed widely between the nine isolates, ranging from $99 \%$ between Mex43 and $\mathrm{Y}^{\mathrm{N}}-\mathrm{M}$ to $84 \%$ between $\mathrm{Y}^{\mathrm{C}}-\mathrm{R}$ and $\mathrm{Y}^{\mathrm{N}}-\mathrm{M}$.

In phylogenetic reconstructions with the nine new sequences, and 56 sequences from nonrecombinants from the GenBank database representing all nonrecombinant PVY phylogroups available at that time, the newly sequenced isolates belonged to major phylogroups $\mathrm{PVY}^{\mathrm{C}}, \mathrm{PVY}^{\mathrm{O}}$, or $\mathrm{PVY}^{\mathrm{N}}$ (Fig. 1). Isolate $\mathrm{Y}^{\mathrm{C}}-\mathrm{R}$ from 1943 was in minor phylogroup $\mathrm{PVY}^{\mathrm{C} 1}$ next to historical potato isolate $\mathrm{Y}^{\mathrm{C}}$-PRI-509 collected in 1938 in the Netherlands (Dullemans et al. 2011). Isolate $\mathrm{Y}^{\mathrm{Z}}-\mathrm{CM} 1$ was in minor phylogroup $\mathrm{PVY} \mathrm{Y}^{\mathrm{O}-\mathrm{O}}$ close to isolate $\mathrm{Y}^{\mathrm{Z}}-\mathrm{CM} 2$ from the same potato cultivar, and in the same minor phylogroup as more contemporary isolate SASA-110 described in 2004 from Scotland (AJ585195; Barker et al. 2009). Isolate $\mathrm{Y}^{\mathrm{N}}-\mathrm{M}$ was placed in minor phylogroup PVY ${ }^{\mathrm{Eu}-\mathrm{N}}$, close to modern PVY $\mathrm{Y}^{\mathrm{Eu}-\mathrm{N}}$ isolate N605 from Switzerland, but separately from other PVY $\mathrm{Yu}^{\mathrm{Eu}}$ isolates from outside Europe. Isolate $\mathrm{Y}^{\mathrm{N}}-\mathrm{RM}$, however, was in minor phylogroup PVY ${ }^{\mathrm{NA}-\mathrm{N}}$, close to modern PVY ${ }^{\mathrm{NA}-\mathrm{N}}$ isolates from North America and Japan. Modern Australian isolate $\mathrm{BL} 2$ was in minor phylogroup $\mathrm{PVY}^{\mathrm{O}-\mathrm{O} 5}$, close to several modern isolates from Australia and North America, but distant from BL, another Australian isolate from the same cultivar, which was in $\mathrm{PVY}{ }^{\mathrm{O}-\mathrm{O}}$. The four modern $\mathrm{PVY}^{\mathrm{N}}$ isolates were all

Table 2. Summary of the biological, serological, and genetic typing data for the historical and contemporary isolates of potato virus $\mathrm{Y}$ characterized in this study

\begin{tabular}{|c|c|c|c|c|c|}
\hline \multirow[b]{2}{*}{ Isolate } & \multirow[b]{2}{*}{ Tobacco reaction $^{\mathbf{a}}$} & \multirow[b]{2}{*}{ Serotype $^{b}$} & \multicolumn{2}{|c|}{ Multiplex RT-PCR ${ }^{c}$} & \multirow[b]{2}{*}{ Genotype, final } \\
\hline & & & (1) & (2) & \\
\hline$\overline{P V Y^{C} \_R}$ & $\mathrm{M}$ & - & none & none & $\mathrm{Y}^{\mathrm{C} 1}$ \\
\hline PVYO_CM1 & M & - & 267,689 & 532,853 & $\mathrm{Y}^{\mathrm{O}-\mathrm{O}}$ \\
\hline BL2 & M & - & 267,689 & 532,853 & $\mathrm{Y}^{\mathrm{O}-\mathrm{O} 5}$ \\
\hline PVYN_RM & VN & - & 328 & 1,307 & $\mathrm{Y}^{\mathrm{NA}-\mathrm{N}}$ \\
\hline WWA150131_G4_8 & $\mathrm{VN}$ & $\mathrm{N}$ & 328,398 & $398,633,1,307$ & $\mathrm{Y}_{\mathrm{Eu}-\mathrm{N}}$ \\
\hline $\operatorname{Mex} 43$ & - & - & 328,398 & $398,633,1,307$ & $\mathrm{Y}^{\mathrm{Eu}-\mathrm{N}}$ \\
\hline PVYN_M & $\mathrm{VN}$ & - & 328,398 & $398,633,1,307$ & $\mathrm{Y}_{\mathrm{Eu}-\mathrm{N}}$ \\
\hline MT12_Oth288 & $\mathrm{VN}$ & $\mathrm{N}$ & 328,398 & $398,633,1,307$ & $Y^{E u-N}$ \\
\hline MT12_Oth295 & $\mathrm{VN}$ & $\mathrm{N}$ & 328,398 & $398,633,1,307$ & $\mathrm{Y}^{\mathrm{Eu}-\mathrm{N}}$ \\
\hline
\end{tabular}

${ }^{a} \mathrm{M}=$ mosaic and vein clearing; $\mathrm{VN}$ = vein necrosis; - = not tested.

b $\mathrm{N}$ designates "N" serotype according to Nikolaeva et al. (2012).

${ }^{c}$ RT-PCR typing was conducted with two primer sets, according to (1) Lorenzen et al. (2006) and (2) Chikh-Ali et al. (2010), numbers are characteristic PCR bands in base pairs (bp); none $=$ no bands produced 


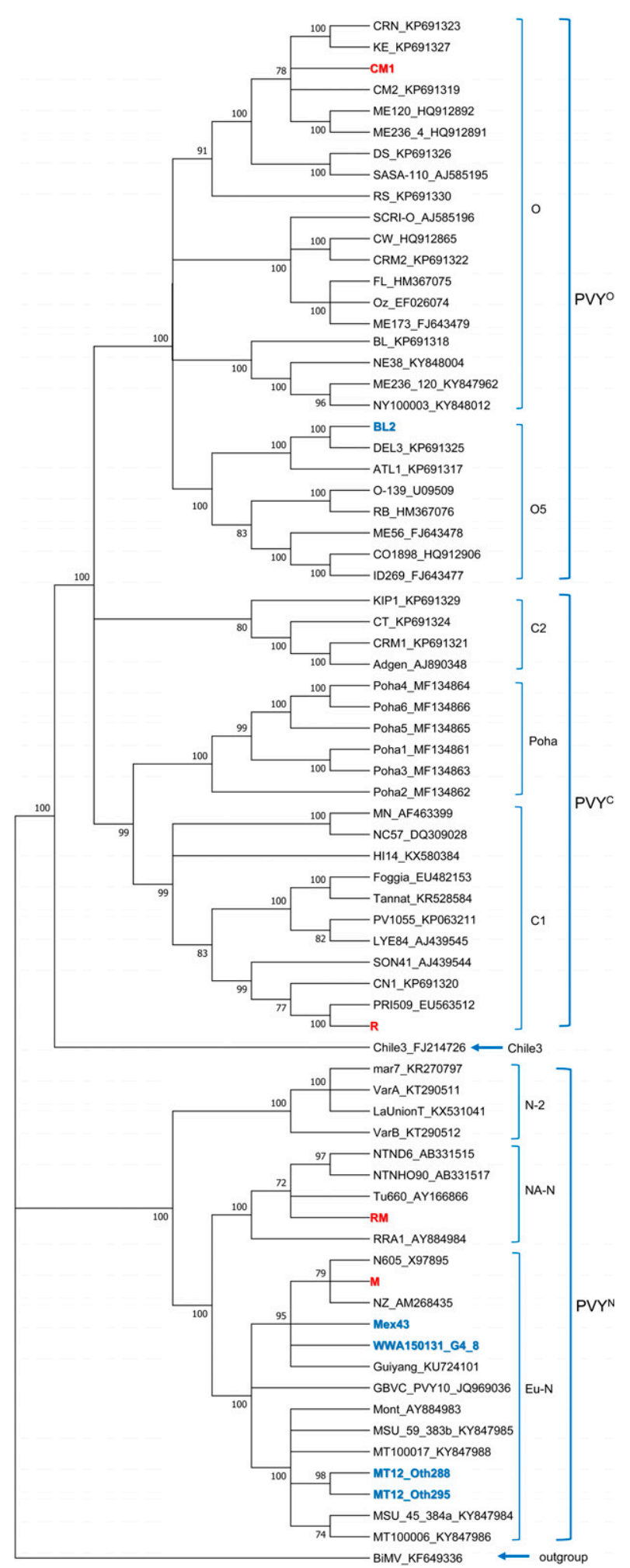

Fig. 1. Condensed, maximum-likelihood phylogenetic tree for the selected full genomes of nonrecombinant potato virus Y (PVY) isolates. Bold red color (lighter gray in print) indicates the "old" (pre-1985), and bold blue color (darker gray in print) indicates "modern" PVY sequences from this study. All other sequences are from the GenBank database. Sequence alignment was done using ClustalW provided in MEGA 7, and the best model was selected by MEGA 7, GTR+I+G (12 Gamma categories). Bootstrap values higher than $70 \%$ are shown at the corresponding nodes. Abbreviations of the PVY isolate names are followed by the corresponding GenBank numbers. Brackets on the right side indicate major phylogroups $\mathrm{PVY}^{\mathrm{O}}, \mathrm{PVY}^{\mathrm{C}}, \mathrm{PVY}^{\mathrm{N}}$, and Chile 3 , and the minor phylogroups within them. Bidens mosaic virus sequence used as outgroup. in minor phylogroup PVYEu-N (Fig. 1). The two modern isolates originally from Montana grouped very closely with several other PVY $^{\mathrm{Eu}-\mathrm{N}}$ sequences from this state, whereas isolates WWA150131_ G4_8 and Mex43 were more distant from both the Montana and UK $\mathrm{PVY}^{\mathrm{Eu}-\mathrm{N}}$ sequences. Thus, although the nomenclature $\mathrm{Y}^{\mathrm{Eu}-\mathrm{N}}$ and $\mathrm{Y}^{\mathrm{NA}-\mathrm{N}}$ is used here, it no longer reflects the geographical origins of isolates within each of these minor phylogroups. Three tomato and one potato PVY isolate sequences from Colombia (LaUnionT, VarA, VarB, and mar7) all fitted within the new South American minor phylogroup N2 recently reported by Fuentes et al. (2019). To assess the robustness of this newly defined South American minor phylogroup, we determined mean group distances within (i) the minor phylogroups defined in Green et al. (2018) and N2 (Table 3), and (ii) between other minor PVY phylogroups (Supplementary Table S1). The genetic distances within each of minor phylogroups $\mathrm{PVY}^{\mathrm{Eu}-\mathrm{N}}, \mathrm{PVY}^{\mathrm{NA}-\mathrm{N}}$, and $\mathrm{PVY}^{\mathrm{N} 2}$ were 3 to 8 times lower than between each of them. Similarly, within minor phylogroups $\mathrm{PVY} \mathrm{Y}^{\mathrm{O}-\mathrm{O}}$ and $\mathrm{PVY}^{\mathrm{O}-\mathrm{O} 5}$, the same mean within phylogroup distances were 2 to 3 times lower than those between $\mathrm{PVY} \mathrm{O}^{\mathrm{O}}$ and $\mathrm{PVY} \mathrm{O}^{\mathrm{O}-\mathrm{O}}$. These findings support separation of $\mathrm{PVY}^{\mathrm{N} 2}$ and $\mathrm{PVY} \mathrm{O}^{\mathrm{O}-5}$ within major phylogroups $\mathrm{PVY}^{\mathrm{N}}$ and $\mathrm{PVY}^{\mathrm{O}}$, respectively (Fig. 1).

Our study confirms that the classical and much studied UK isolate $\mathrm{Y}^{\mathrm{C}}$-R from 1943 (Bawden and Kassanis 1947; Jones 1990; Kassanis and Govier 1971; Kehoe and Jones 2011, 2016) fits closely with classical Netherlands isolate $\mathrm{Y}^{\mathrm{C}}$-PRI-509 (EU563512) from 1938 (Dullemans et al. 2011) within minor phylogroup PVY ${ }^{\mathrm{C} 1}$. As mentioned above, $\mathrm{PVY}^{\mathrm{C} 1}$ contains isolates from many solanaceous species (Dullemans et al. 2011; Fuentes et al. 2019; Gibbs et al. 2017; Green et al. 2017b; Kerlan and Moury 2008; Quenouille et al. 2013). This finding is significant as, apart from $Y^{\mathrm{C}}$-PRI-509, all other $\mathrm{PVY}^{\mathrm{C}}$ sequences from potato fit within minor phylogroup $\mathrm{PVY} \mathrm{C}^{\mathrm{C}}$ (Green et al. 2017b; Jones and Kehoe 2016). Our research also identifies the oldest examples of complete genomic sequences belonging to minor phylogroups PVY ${ }^{\mathrm{NA}-\mathrm{N}}$ and $\mathrm{PVY} \mathrm{Y}^{\mathrm{Eu}-\mathrm{N}}$, as a newly sequenced historical UK $\mathrm{Y}^{\mathrm{N}}$ isolate belonged to each of them. This shows that both PVY ${ }^{\text {NA-N }}$ and PVY ${ }^{\mathrm{Eu}-\mathrm{N}}$ were present in UK in the early 1980s. Our four new examples of modern nonrecombinant PVY isolates from Mexico and the U.S.A. were all in minor phylogroup PVY ${ }^{\mathrm{Eu}-\mathrm{N}}$ (Fig. 1). Moreover, our study and that of Kehoe and Jones (2016) agree in finding no recombinant PVY isolates in the UK in the first half of the 1980 s as neither the eight genomes sequenced previously from UK isolates from 1943 to 1984 nor the four PVY isolates from that era sequenced in our study were recombinants. This suggests that much of the sequence diversity now known to occur among nonrecombinant PVY isolates was already present in the UK by 1984. Similarly, neither the five recently sequenced PVY isolates from Western Australia obtained by Kehoe and Jones (2016) nor the one sequenced here were recombinants, suggesting recombinant PVY has not yet arrived in this isolated world region. Furthermore, our study found all three historical $\mathrm{PVY}^{-\mathrm{Z}}$ strain group

Table 3. Mean group distances within minor phylogroups of potato virus $Y$

\begin{tabular}{lcc}
\hline & \multicolumn{2}{c}{ Within strain - mean group distance } \\
\cline { 2 - 3 } Minor phylogroup & $\mathbf{d}^{\mathbf{a}}$ & Standard error \\
\hline C & 0.100 & 0.003 \\
Chile3 & $\mathrm{n} / \mathrm{a}$ & $\mathrm{n} / \mathrm{a}$ \\
Eu-N & 0.008 & 0.001 \\
NA-N & 0.007 & 0.000 \\
O & 0.018 & 0.001 \\
O5 & 0.014 & 0.001 \\
Outgroup & $\mathrm{n} / \mathrm{a}$ & $\mathrm{n} / \mathrm{a}$ \\
N2 & 0.017 & 0.001 \\
\hline
\end{tabular}

${ }^{a}$ Distances between minor phylogroups defined by Green et al. (2018), and Colombian sequences within South American minor phylogroup N2 defined by Fuentes et al. (2019). Distances were produced in MEGA 7 using the maximum likelihood method with 100 bootstrap replicates. Model selected as best by MEGA 7: GTR+I+G (12 Gamma categories). $\mathrm{n} / \mathrm{a}=$ not applicable as only one isolate present. 
nonrecombinant isolates $\left(\mathrm{Y}^{\mathrm{Z}}{ }_{-} \mathrm{CM} 2, \mathrm{Y}^{\mathrm{Z}}-\mathrm{CRM} 2, \mathrm{Y}^{\mathrm{Z}}-\mathrm{DS}\right)$ to be within minor phylogroup $\mathrm{PVY} \mathrm{Y}^{\mathrm{O}-\mathrm{O}}$, and three of the four modern Australian isolates to be within minor phylogroup $\mathrm{PVY}{ }^{\mathrm{O}-\mathrm{O} 5}$; Kehoe and Jones (2016) had previous misplaced five historical $\mathrm{PVY} \mathrm{O}^{\mathrm{O} O}$ isolates $\left(\mathrm{Y}^{\mathrm{Z}}-\mathrm{CM} 2, \mathrm{Y}^{\mathrm{Z}}-\mathrm{DS}, \mathrm{Y}^{\mathrm{O}}-\mathrm{CRN}, \mathrm{Y}^{\mathrm{O}}-\mathrm{KE}, \mathrm{Y}^{\mathrm{O}}-\mathrm{RS}\right)$ within $\mathrm{PVY} \mathrm{Y}^{\mathrm{O}-\mathrm{O} 5}$.

In 1984, Beczner et al. (1984) first reported presence of PTNRD caused by PVY in Hungary. When European PVY isolates associated with PTNRD were sequenced, they proved to be recombinants between PVY ${ }^{\mathrm{O}}$ and $\mathrm{PVY}^{\mathrm{N}}$ (Boonham et al. 1999, 2002; Glais et al. 1998, 2002; Revers et al. 1996). After the 1980s, recombinant PVYs largely displaced nonrecombinants in Europe, and after that in North America and many other world regions (Funke et al. 2017; Karasev and Gray 2013a, b). The lack of detection of any recombinants among the 11 historical $\mathrm{PVY}^{\mathrm{O}}$ and $\mathrm{PVY}^{\mathrm{N}}$ isolates first obtained in 1981 to 1984 (Table 1) suggest they were absent or uncommon in the UK at that time. The same is also likely for the rest of Europe.

Why do the two oldest potato PVY sequences occur in otherwise non-potato minor phylogroup $\mathrm{PVY}^{\mathrm{Cl}}$ ? These two isolates were obtained in the Netherlands or UK in 1939 and 1943, respectively, i.e., 77 to 81 years ago (Table 1). Apparently, such potato isolates were relatively common then, but disappeared subsequently as none were found in the 1980s when several PVY ${ }^{\mathrm{C} 2}$ isolates were detected in the UK (Jones 1990; Kehoe and Jones 2011, 2016) and none were found subsequently. Greater abundance of hypersensitivity gene $N c$ in potato cultivars after the 1940s might explain this apparent disappearance, but this explanation is inconsistent with the ease of finding isolates in minor phylogroup $\mathrm{PVY}^{\mathrm{C} 2}$ in the $\mathrm{UK}$ in the early 1980s (Cockerham 1943, 1970; Jones 1990). Another possible explanation is that, being less well adapted to infect potato, $\mathrm{PVY}^{\mathrm{C} 1}$ isolates were displaced by $\mathrm{PVY}^{\mathrm{C} 2}$ isolates in potato cultivars without gene $N c$. The predominance of isolates infecting tobacco, pepper, tomato, and other solanaceous crops in $\mathrm{PVY}^{\mathrm{Cl}}$ (Fuentes et al. 2019; Gibbs et al. 2017; Green et al. 2017b; Kehoe and Jones 2016; Kerlan and Moury 2008; Moury 2010; Quenouille et al. 2013) seems consistent with this explanation.

\section{Acknowledgments}

We would like to thank C. Funke, L. Tran, and J. Chojnacky for help with virus maintenance and testing, and Eva Gajda for providing Australian isolate BL2.

\section{Literature Cited}

Altschul, S. F., Gish, W., Miller, W., Myers, E. W., and Lipman, D. J. 1990. Basic local alignment search tool. J. Mol. Biol. 215:403-410.

Barker, H., McGeachy, K. D., Toplak, N., Gruden, K., Zel, J., and Browning, I. 2009. Comparison of genome sequence of PVY isolates with biological properties. Am. J. Potato Res. 86:227-238.

Bawden, F. C., and Kassanis, B. 1946. Varietal differences in susceptibility to potato virus Y. Ann. Appl. Biol. 33:46-50.

Bawden, F. C., and Kassanis, B. 1947. The behaviour of some naturally occurring strains of potato virus Y. Ann. Appl. Biol. 34:503-516.

Beczner, L., Horvath, J., Romhanyi, I., and Förster, H. 1984. Studies on the etiology of tuber necrotic ringspot disease in potato. Potato Res. 27:339-352.

Blanchard, A., Rolland, M., Lacroix, C., Kerlan, C., and Jacquot, J. 2008. Potato virus $Y$ : a century of evolution. Curr. Top. Virol. 7:21-32.

Boni, M. F., Posada, D., and Feldman, M. W. 2007. An exact nonparametric method for inferring mosaic structure in sequence triplets. Genetics 176: 1035-1047.

Boonham, N., Hims, M., Barker, I., and Spence, N. 1999. Potato virus Y from petunia can cause symptoms of potato tuber necrotic ringspot disease (PTNRD). Eur. J. Plant Pathol. 105:617-621.

Boonham, N., Walsh, K., Hims, M., North, J., and Barker, I. 2002. Biological and sequence comparisons of Potato virus $Y$ isolates associated with potato tuber necrotic ringspot disease. Plant Pathol. 51:117-126.

Chikh-Ali, M., Gray, S. M., and Karasev, A. V. 2013. An improved multiplex ICRT-PCR assay distinguishes nine strains of Potato virus Y. Plant Dis. 97: 1370-1374.

Chikh-Ali, M., Maoka, T., Natsuaki, K. T., and Natsuaki, T. 2010. The simultaneous differentiation of Potato virus $Y$ strains including the newly described strain PVY ${ }^{\text {NTN-NW }}$ by multiplex PCR assay. J. Virol. Methods 165:15-20.

Chikh-Ali, M., Rowley, J. S., Kuhl, J., Gray, S., and Karasev, A. V. 2014. Evidence of a monogenic nature of the $\mathrm{Nz}$ gene conferring resistance against Potato virus $Y$ strain Z (PVYZ) in potato. Am. J. Potato Res. 91:649-654.
Chikh-Ali, M., Vander Pol, D., Nikolaeva, O. V., Melzer, M. J., and Karasev, A. V. 2016. Biological and molecular characterization of a tomato isolate of Potato virus $\mathrm{Y}$ (PVY) of the PVYC lineage. Arch. Virol. 161:3561-3566.

Chung, B. Y. W., Miller, W. A., Atkins, J. F., and Firth, A. E. 2008. An overlapping essential gene in the Potyviridae. Proc. Nat. Acad. Sci. USA 105:5897-5902.

Cockerham, G. 1943. The reactions of potato varieties to viruses X, A, B and C. Ann. Appl. Biol. 30:338-344.

Cockerham, G. 1970. Genetical studies on resistance to potato viruses X and Y Heredity 25:309-348.

Coutts, B. A., and Jones, R. A. C. 2015. Potato virus Y: contact transmission, stability, inactivation, and infection sources. Plant Dis. 99:387-394.

Dellaporta, S. L., Woods, J., and Hicks, J. B. 1983. A plant DNA mini-preparation: version II. Plant Mol. Biol. Report. 1:19-21.

Dullemans, A. M., Cuperus, C., Verbeek, M., and van der Vlught, R. A. A. 2011 Complete nucleotide sequence of a potato isolate of strain group C of Potato virus $Y$ from 1938. Arch. Virol. 156:473-477.

Edgar, R. C. 2004. MUSCLE: multiple sequence alignment with high accuracy and high throughput. Nucleic Acids Res. 32:1792-1797.

FAOSTAT. 2017. Food and Agriculture Organization of the United Nations. http://www.fao.org/faostat/en/\#search/Potatoes.

Fuentes, S., Jones, R. A. C., Matsuoka, H., Ohshima, K., Kreuze, J., and Gibbs, A. J. 2019. Potato virus $Y$; the Andean connection. Virus Evol. 5:vez037.

Funke, C. N., Nikolaeva, O. V., Green, K. J., Tran, L. T., Chikh-Ali, M., QuinteroFerrer, A., Cating, R. A., Frost, K. E., Hamm, P. B., Olsen, N., Pavek, M. J., Gray, S. M., Crosslin, J. M., and Karasev, A. V. 2017. Strain-specific resistance to Potato virus $Y$ (PVY) in potato and its effect on the relative abundance of PVY strains in commercial potato fields. Plant Dis. 101:20-28.

Gibbs, A. J., Ohshima, K., Yasaka, R., Mohammad, M., Gibbs, M. J., and Jones, R. A. C. 2017. The phylogenetics of the global population of potato virus $Y$ and its necrogenic recombinants. Virus Evol. 3:vex002.

Gibbs, M. J., Armstrong, J. S., and Gibbs, A. J. 2000. Sister-scanning: a Monte Carlo procedure for assessing signals in recombinant sequences. Bioinformatics 16:573-582.

Glais, L., Tribodet, M., Gauthier, J. P., Astier-Manifacier, S., Robaglia, C., and Kerlan, C. 1998. RFLP mapping of the whole genome of ten viral isolates representative of different biological groups of potato virus Y. Arch. Virol. 143:2077-2091.

Glais, L., Tribodet, M., and Kerlan, C. 2002. Genomic variability in potato potyvirus Y (PVY): evidence that PVYNW and PVYNTN variants are single to multiple recombinants between PVYO and PVYN isolates. Arch. Virol. 147:363-378.

Gray, S., De Boer, S., Lorenzen, J., Karasev, A., Whitworth, J., Nolte, P., Singh, R., Boucher, A., and $\mathrm{Xu}, \mathrm{H} .2010$. Potato virus $Y$ : an evolving concern for potato crops in the United States and Canada. Plant Dis. 94:1384-1397.

Green, K. J., Brown, C. J., Gray, S. M., and Karasev, A. V. 2017a. Phylogenetic study of recombinant strains of Potato virus Y. Virology 507:40-52.

Green, K. J., Brown, C. J., and Karasev, A. V. 2018. Genetic diversity of potato virus Y (PVY): sequence analyses reveal ten novel PVY recombinant structures. Arch. Virol. 163:23-32.

Green, K. J., Chikh-Ali, M., Hamasaki, R. T., Melzer, M. J., and Karasev, A. V. 2017b. Potato virus Y (PVY) isolates from Physalis peruviana are unable to systemically infect potato or pepper and form a distinct new lineage within the PVYC ${ }^{\mathrm{C}}$ strain group. Phytopathology 107:1433-1439.

Hu, X., Meacham, T., Ewing, L., Gray, S. M., and Karasev, A. V. 2009. A novel recombinant strain of Potato virus $Y$ suggests a new viral genetic determinant of vein necrosis in tobacco. Virus Res. 143:68-76.

Jones, R. A. C. 1990. Strain group specific and virus specific hypersensitive reactions to infection with potyviruses in potato cultivars. Ann. Appl. Biol. 117:93-105.

Jones, R. A. C. 2014. Virus disease problems facing potato industries worldwide: viruses found, climate change implications, rationalising virus strain nomenclature and addressing the Potato virus $Y$ issue. Pages 202-224 in: The Potato: Botany, Production and Uses. R. Navarre and M. J. Pavek, eds. CABI, Wallingford, UK.

Jones, R. A. C., and Kehoe, M. A. 2016. A proposal to rationalize within-species plant virus nomenclature: benefits and implications of inaction. Arch. Virol. 161:2051-2057.

Jones, R. A. C., and Vincent, S. J. 2018. Strain-specific hypersensitive and extreme resistance phenotypes elicited by Potato virus Y amongst 39 potato cultivars released in three world regions over a 117 year period. Plant Dis. 102:185-196.

Karasev, A. V., and Gray, S. M. 2013a. Continuous and emerging challenges of Potato virus $Y$ in Potato. Annu. Rev. Phytopathol. 51:571-586.

Karasev, A. V., and Gray, S. M. 2013b. Genetic diversity of Potato virus $Y$ complex. Am. J. Potato Res. 90:7-13.

Karasev, A. V., Hu, X., Brown, C. J., Kerlan, C., Nikolaeva, O. V., Crosslin, J. M., and Gray, S. M. 2011. Genetic diversity of the ordinary strain of Potato virus $Y$ (PVY) and origin of recombinant PVY strains. Phytopathology 101:778-785.

Karasev, A. V., Nikolaeva, O. V., Hu, X., Sielaff, Z., Whitworth, J., Lorenzen, J. H., and Gray, S. M. 2010. Serological properties of ordinary and necrotic isolates of Potato virus $Y$ : a case study of $\mathrm{PVY}^{\mathrm{N}}$ misidentification. Am. J. Potato Res. 87:1-9. 
Kassanis, B., and Govier, D. A. 1971. New evidence on the mechanism of aphid transmission of potato $\mathrm{C}$ and potato aucuba mosaic viruses. J. Gen. Virol. 10: 99-101.

Kehoe, M. A., and Jones, R. A. C. 2011. A proposal to help resolve the disagreement between naming of potato virus Y strain groups defined by resistance phenotypes and those defined by sequencing. Arch. Virol. 156:2273-2278.

Kehoe, M. A., and Jones, R. A. C. 2016. Improving Potato virus $Y$ strain nomenclature: lessons from comparing isolates obtained over a 73 year period. Plant Pathol. 65:322-333.

Kerlan, C. 2006. Potato virus Y. Descriptions of Plant Viruses, No. 414. Association of Applied Biologists, Wellesbourne, UK

Kerlan, C., and Moury, B. 2008. Potato virus Y. Pages 287-296 in: Encyclopedia of Virology, 3rd Ed. A. Granoff and R. Webster, eds. Academic Press, New York.

Kerlan, C., Nikolaeva, O. V., Hu, X., Meacham, T., Gray, S. M., and Karasev, A. V. 2011. Identification of the molecular make-up of the Potato virus $Y$ strain $\mathrm{PVY}^{\mathrm{Z}}$ : Genetic typing of $\mathrm{PVY}^{\mathrm{Z}}-\mathrm{NTN}$. Phytopathology 101: 1052-1060.

Kreuze, J. F., Souza-Dias, J. A. C., Jeevalatha, A., Figueira, A. R., Valkonen, J. P. T., and Jones, R. A. C. 2020. Viral Diseases in Potato. Pages 389-430 in: The Potato Crop. H. Campos and O. Ortiz, eds. Springer, Cham, Switzerland.

Lorenzen, J. H., Piche, L. M., Gudmestad, N. C., Meacham, T., and Shiel, P. 2006. A multiplex PCR assay to characterize Potato virus $Y$ isolates and identify strain mixtures. Plant Dis. 90:935-940.

Martin, D., and Rybicki, E. 2000. RDP: detection of recombination amongst aligned sequences. Bioinformatics 16:562-563.

Martin, D., Williamson, C., and Posada, D. 2005. RDP2: recombination detection and analysis from sequence alignment. Bioinformatics 21:260-262.

Maynard-Smith, J. 1992. Analyzing the mosaic structure of genes. J. Mol. Evol. 34:126-129.

Moury, B. 2010. A new lineage sheds light on the evolutionary history of Potato virus Y. Mol. Plant Pathol. 11:161-168.

Moury, B., Morel, C., Johansen, E., and Jacquemond, M. 2002. Evidence for diversifying selection in potato virus $\mathrm{Y}$ and in the coat protein of other potyviruses. J. Gen. Virol. 83:2563-2573.

Ndunguru, J., Taylor, N. J., Yadav, J., Aly, H., Legg, J. P., Aveling, T., Thompson, G., and Fauquet, C. M. 2005. Application of FTA technology for sampling, recovery and molecular characterization of viral pathogens and virus-derived transgenes from plant tissues. Virol. J. 2:45.
Nikolaeva, O. V., Roop, D., Galvino-Costa, S. F. B., Figueira, A. R., Gray, S. M and Karasev, A. V. 2012. Epitope mapping for monoclonal antibodies recognizing tuber necrotic strains of Potato virus $Y$. Am. J. Potato Res. 89 121-128.

Posada, D., and Crandall, K. A. 2001. Evaluation of methods for detecting recombination from DNA sequences: computer simulations. Proc. Nat. Acad. Sci. USA 98:13757-13762.

Quenouille, J., Vassilakos, N., and Moury, B. 2013. Potato virus Y: a major crop pathogen that has provided major insights into the evolution of viral pathogenicity. Mol. Plant Pathol. 14:439-452.

Revers, F., Le Gall, O., Candresse, T., Le Romancer, M., and Dunez, J. 1996 Frequent occurrence of recombinant potyvirus isolates. J. Gen. Virol. 77: 1953-1965

Rowley, J. S., Gray, S. M., and Karasev, A. V. 2015. Screening potato cultivars for new sources of resistance to Potato virus Y. Am. J. Potato Res. 92:38-48.

Salminen, M. O., Carr, J. K., Burke, D. S., and McCutchan, F. E. 1995. Identification of breakpoints in intergenotypic recombinants of HIV type 1 by bootscanning. AIDS Res. Human Retroviruses. November 1995:1423-1425.

Sanches, M. M., De Marchi, B. R., Spadotti, D. M., Nozaki, D. N., Pavan, M. A. and Krause-Sakate, R. 2014. Biological and molecular characterisation of Bidens mosaic virus supports its assignment as a member of a distinct species in the genus Potyvirus. Arch. Virol. 159:2181-2183.

Sawyer, S. A. 1999. GENECONV: a computer package for the statistical detection of gene conversion. Distributed by the Author. Department of Mathematics. Washington University, St. Louis, MO. http://www.math.wustl.edu/ $\sim$ sawyer

Singh, M., and Singh, R. P. 1996. Nucleotide sequence and genome organization of a Canadian isolate of the common strain of potato virus $\mathrm{Y}(\mathrm{PVY})$. Can. J. Plant Pathol. 18:209-224.

Singh, R. P., Valkonen, J. P. T., Gray, S. M., Boonham, N., Jones, R. A. C., Kerlan, C., and Schubert, J. 2008. Discussion paper: The naming of Potato virus $Y$ strains infecting potato. Arch. Virol. 153:1-13.

Tamura, K., Stecher, G., Peterson, D., Filipski, A., and Kumar, S. 2013. MEGA6: Molecular Evolutionary Genetics Analysis version 6.0. Mol. Biol. Evol. 30 2725-2729.

Valkonen, J. P. T. 2007. Viruses: economical losses and biotechnological potential. In Potato biology and biotechnology. Pages 619-641 in: Potato Biology and Biotechnology. D. Vreugdenhil, ed. Elsevier, Oxford, UK. 